\title{
Production and partial purification of proteases from Aspergillus oryzae grown in a medium based on whey protein as an exclusive nitrogen source
}

\author{
H. Kumura, ${ }^{1}$ T. Ishido, and K. Shimazaki \\ Laboratory of Dairy Food Science, Division of Bioresources and Product Science, Hokkaido University, Kita 9, Nishi 9, 060-8589, Sapporo, Japan
}

\begin{abstract}
Several attempts have been made to incorporate whey proteins into curd to increase cheese yield. For some types of cheese, degradation of whey proteins that have been incorporated into the curd would be required to obtain acceptable flavor and texture. On the basis of the high potential for protease synthesis in Aspergillus oryzae, sodium nitrate as a nitrogen source in a minimal medium for fungi, known as Czapek-Dox medium, was replaced with whey protein isolate to induce the protease to hydrolyze whey protein using A. oryzae AHU7146. A solid-phase medium adjusted to $\mathrm{pH} 6$ was suitable for this purpose when incubation was carried out at $25^{\circ} \mathrm{C}$ for $2 \mathrm{wk}$. The application of column chromatography enabled the resolution of 3 proteolytic components (1, 2 , and 3). With respect to optimal temperature and zymographic analysis, component 1 was similar to component 3 . In contrast, component 2 was less abundant than the other components and exhibited activity in the alkaline $\mathrm{pH}$ region. The degradation of $\beta$-lactoglobulin and $\alpha$-lactalbumin in whey protein isolate solution by the crude enzyme was primarily attributed to the action of components 1 and 3, based on HPLC analysis and the N-terminal amino acid sequences; however, zymography demonstrated evident proteolysis due to component 2. Because heat-denatured whey protein aggregates were digestible by the crude enzyme, the proteolytic system from $A$. oryzae has the potential as an additive to stimulate the ripening of cheese enriched with whey protein.
\end{abstract}

Key words: whey protein, Aspergillus oryzae, protease

\section{INTRODUCTION}

Whey, as a byproduct from the manufacture of cheese, comprises 85 to $90 \%$ of the total volume of the original milk and retains about $50 \%$ of the nutrients. To increase cheese yields, several attempts have been made

Received June 2, 2010.

Accepted October 12, 2010.

${ }^{1}$ Corresponding author: kumura@anim.agr.hokudai.ac.jp to incorporate whey proteins into curd. The technologies associated with this objective are high heat treatment, ultrafiltration, particulation, and the addition of transglutaminase after the rennet coagulation of milk (Hinrichs, 2001; Cozzolino et al., 2003). A high preheating temperature or ultrafiltration could improve the yield and texture of fresh cheese due to increased water binding to the denatured whey proteins; however, the type of cheese should be considered if these technologies are applied because the heating of concentrated milk to high temperatures could influence the composition and ripening of the cheese, which would result in a slightly poor quality with respect to flavor and texture for some kinds of cheese (Hinrichs, 2001).

Bovine milk protein consists of approximately $20 \%$ whey protein that includes $\beta$-LG and $\alpha$-LA as the predominant proteins. Whey proteins are well known for their high nutritional value (Hambræus and Lönnerdal, 2003) and their functional characteristics of gelation and foaming properties (Mangino, 1992; Dickinson, 2003; Singh and Havea, 2003). Therefore, whey proteins have been incorporated into food products, including dairy products, infant formula, and bakery products, among others (Hoppe and Higgins, 1992; Mulvihill and Ennis, 2003). Moreover, numerous studies have shown that peptides from whey protein exhibit various physiological activities such as opioid-like properties, antihypertensive activity, and immune modulation (FitzGerald and Meisel, 2003; Madureira et al., 2010). The extensive hydrolysis of whey protein, in particular of $\beta-L G$, would be advantageous to reduce allergenicity of $\beta-\mathrm{LG}$ (Peñas et al., 2006; Morisawa et al., 2009). Because $\beta-L G$ and $\alpha$-LA tend to be more resistant to bacterial protease than casein, which is possibly due to their globular structure (Fairbairn and Law, 1986; Madureira et al., 2010), it would be ideal to incorporate whey protein to add intensively proteolytic microorganisms to the starter, including microorganisms used for mold-type cheeses or smear-ripened cheese, to improve cheese flavor and texture. The maturation of the smear- ripened cheese and white-mold cheese proceeds gradually from the surface to the inner part of the curd, whereas the ripening of blue-veined cheese occurs rather uniformly. Therefore, if the proteolytic system of the starter mi- 
croorganism associated with blue-veined cheese could act on whey protein that had been incorporated into the cheese curd, the liberation of the peptides from whey protein, leading to the development of novel types of flavors, could be expected. However, our preliminary study confirmed the low digestibility of protease from Penicillium roqueforti, isolated from commercial cheese, on whey protein.

In contrast, Aspergillus oryzae, the so-called koji molds, have been used extensively for indigenous Japanese fermentation products such as sake (rice wine), shochu (spirits), shoyu (soy sauce), and miso (soybean paste) for more than 1,000 years (Machida, 2002; Yu et al., 2004). The long history of extensive use in food industries prompted the US FDA to place A. oryzae on the list of generally regarded as safe organisms. The safety of $A$. oryzae is also supported by the World Health Organization (Taylor and Richardson, 1979; Barbesgaard et al., 1992; Machida, 2002). The genomics research of A. oryzae is complete, and 135 genes encoding secreted proteinases have been found (Machida et al., 2005). Recently, Izumi et al. (2009) studied the effect of $\alpha$-LA and its hydrolysates on the concentration of glucagon-like peptide-2 (GLP-2) in serum using suckling rats. They observed that the oral administration of a hydrolysate of $\alpha$-LA by a commercial protease preparation from $A$. oryzae led to almost twice the GLP-2 release in serum compared with that from intact $\alpha-\mathrm{LA}$ and other $\alpha$-LA hydrolysates. Moreover, the length of the small intestine and the number of epithelial cells per crypt were increased when the hydrolysate of $\alpha$-LA by commercial protease from $A$. oryzae was given compared with the results from giving intact $\alpha$-LA, which indicated that the hydrolysate promoted GLP-2 secretion along with a contribution to growth and maturation of the small intestine. Therefore, whey protein digested by proteases, in particular derived from $A$. oryzae, could be used not solely as foodstuff (such as seasoning, sauce, confectionary, and an additive to dairy and meat products) to add nutritional value, but as a functional food.

In this study, the nitrogen source in a minimal medium for fungi was replaced with whey protein to induce proteinases responsible for whey protein digestion from A. oryzae. Furthermore, the fractionation and partial characterization of the proteinase were performed to evaluate its potential for use in the cheese industry.

\section{MATERIALS AND METHODS}

\section{Strain and Growth Medium}

Aspergillus oryzae AHU7146, originally isolated from miso and maintained in the culture collection of Hokkaido University, was grown in potato dextrose agar
(Merck KGaA, Darmstadt, Germany) at $25^{\circ} \mathrm{C}$ for 2 wk. The conidia were isolated and dispersed in $0.9 \% \mathrm{NaCl}$ solution.

The medium for protease production was based on the minimum medium for fungi, Czapek-Dox. Sodium nitrate was replaced as the nitrogen source with whey protein isolate (WPI). The final medium content was as follows: $0.05 \%$ of $\mathrm{KCl}, 0.1 \%$ of $\mathrm{KH}_{2} \mathrm{PO}_{4}, 0.1 \%$ of $\mathrm{MgSO}_{4} \cdot 7 \mathrm{H}_{2} \mathrm{O}, 0.002 \%$ of $\mathrm{FeSO}_{4} \cdot 7 \mathrm{H}_{2} \mathrm{O}, 3.6 \%$ of glucose, and $5 \%$ of WPI; this medium was prepared and adjusted to a final $\mathrm{pH}$ of $4.0,5.0$, or 6.0 with $1 \mathrm{M} \mathrm{HCl}$. The solution was aliquoted $(15 \mathrm{~mL})$ in an Erlenmeyer flask $(100 \mathrm{~mL})$ and autoclaved to prepare the solidphase medium. Alternatively, the liquid-phase medium was prepared as follows: $15 \mathrm{~mL}$ of the solution, whose $\mathrm{pH}$ value was adjusted to 8.4, was filter-sterilized and recovered in an Erlenmeyer flask $(100 \mathrm{~mL})$; filtration was followed by the addition of $0.7 \mathrm{~mL}$ of $1 \mathrm{M} \mathrm{HCl}$ to adjust the $\mathrm{pH}$ value to 6.0. Each medium-containing Erlenmeyer flask $(100 \mathrm{~mL})$ received $3.5 \times 10^{4}$ conidia and was maintained at $15,20,25$, or $30^{\circ} \mathrm{C}$ for 1,2 , or 4 wk. Unless otherwise stated, the $\mathrm{pH}$ value of the medium was adjusted to 6.0 before autoclaving, and incubation was carried out at $25^{\circ} \mathrm{C}$ for $2 \mathrm{wk}$.

\section{Preparation and Purification of the Enzyme}

The extraction of the enzyme was performed as follows: $10 \mathrm{~mL}$ of distilled water was added to the Erlenmeyer flask containing solid-phase medium previously inoculated with $A$. oryzae AHU7146, and the medium and sample were pounded to clots. The material was transferred to a polyethylene bag. The sample was treated by a stomacher and transferred to a centrifugal tube. Following centrifugation at $10,000 \times g$ and $4^{\circ} \mathrm{C}$ for $15 \mathrm{~min}$, the supernatant was recovered and solid ammonium sulfate was added to yield $90 \%$ saturation. The precipitate was collected by centrifugation at $10,000 \times$ $g$ and $4^{\circ} \mathrm{C}$ for $15 \mathrm{~min}$ and dissolved in $1 \mathrm{~mL}$ of $0.02 \mathrm{M}$ sodium phosphate buffer at $\mathrm{pH}$ 6.0. The resulting solution was used as a crude enzyme.

The crude enzyme was extensively dialyzed against $0.02 \mathrm{M}$ sodium phosphate buffer at $\mathrm{pH} 6.0$ and applied to a column $(10 \times 100 \mathrm{~mm})$ of Butyl-Toyopearl $650 \mathrm{~S}$ (Tosoh, Tokyo, Japan) that was pre-equilibrated with the same buffer. The column was washed thoroughly with the same buffer to remove unadsorbed materials. The adsorbed materials were then eluted by a linear gradient of $(0-50 \%)$ ethanol in the same buffer $(30$ $\mathrm{mL}$ ), and the elution was continued using $50 \%$ ethanol in the same buffer $(10 \mathrm{~mL})$ at a flow rate of $1 \mathrm{~mL} /$ min. Proteinase-rich fractions were pooled and applied to a column $(10 \times 100 \mathrm{~mm})$ of DEAE-Toyopearl $650 \mathrm{M}$ (Tosoh) that was pre-equilibrated with $0.02 M$ sodium 
Table 1. Production of protease ${ }^{1}$ of Aspergillus oryzae AHU7146 under various $\mathrm{pH}$ and temperature conditions for defined incubation periods ${ }^{2}$

\begin{tabular}{lccc}
\hline & \multicolumn{3}{c}{ Incubation period } \\
\cline { 2 - 4 } $\mathrm{pH}$ and & $1 \mathrm{wk}$ & $2 \mathrm{wk}$ & $4 \mathrm{wk}$ \\
\hline temperature & & & \\
$\mathrm{pH} 4.0$ & $3.2 \pm 0.4$ & $7.5 \pm 0.6$ & $3.1 \pm 0.0$ \\
$15^{\circ} \mathrm{C}$ & $4.8 \pm 0.2$ & $1.5 \pm 0.2$ & $2.0 \pm 0.3$ \\
$20^{\circ} \mathrm{C}$ & $3.9 \pm 1.9$ & $0.6 \pm 0.2$ & $1.3 \pm 2.7$ \\
$25^{\circ} \mathrm{C}$ & $1.3 \pm 0.2$ & $6.9 \pm 1.2$ & \\
$30^{\circ} \mathrm{C}$ & & & $4.3 \pm 0.2$ \\
$\mathrm{pH} 5.0$ & $4.0 \pm 0.3$ & $6.3 \pm 0.7$ & $4.7 \pm 0.4$ \\
$15^{\circ} \mathrm{C}$ & $4.3 \pm 0.5$ & $5.0 \pm 0.0$ & $1.9 \pm 0.5$ \\
$20^{\circ} \mathrm{C}$ & $1.9 \pm 0.1$ & $2.5 \pm 0.5$ & \\
$25^{\circ} \mathrm{C}$ & $1.4 \pm 0.0$ & $3.1 \pm 0.3$ & $3.4 \pm 0.2$ \\
$30^{\circ} \mathrm{C}$ & & & $19.2 \pm 3.6$ \\
$\mathrm{pH} 6.0$ & $4.3 \pm 0.3$ & $5.9 \pm 0.7$ & $4.2 \pm 0.3$ \\
$15^{\circ} \mathrm{C}$ & $5.6 \pm 0.2$ & $4.8 \pm 0.4$ & $4.4 \pm 1.8$ \\
$20^{\circ} \mathrm{C}$ & $4.0 \pm 0.2$ & $15.9 \pm 1.4$ & $10.6 \pm 0.4$ \\
$25^{\circ} \mathrm{C}$ & $1.9 \pm 0.5$ & & \\
$30^{\circ} \mathrm{C}$ & & & \\
\hline
\end{tabular}

${ }^{1}$ Protease activity in the crude enzyme was expressed in protease units $(\mathrm{PU}) / \mathrm{mL}$; see details in text.

${ }^{2}$ Average value \pm standard error is shown from 2 determinations per experiment from 2 experiments.

phosphate buffer at $\mathrm{pH}$ 6.0. The column was washed thoroughly with the same buffer to remove unadsorbed materials, and the adsorbed materials were then eluted by a linear gradient of $(0$ to $1 M) \mathrm{NaCl}$ in the same buffer $(30 \mathrm{~mL})$. The elution was then continued using $2 \mathrm{M} \mathrm{NaCl}$ in the same buffer $(10 \mathrm{~mL})$ at a flow rate of $1 \mathrm{~mL} / \mathrm{min}$.

The materials unadsorbed to Butyl-Toyopearl 650S were directly applied to a column $(10 \times 440 \mathrm{~mm})$ of DEAE-Toyopearl $650 \mathrm{M}$ (Tosoh) that was pre-equilibrated with $0.02 M$ sodium phosphate buffer at $\mathrm{pH}$ 6.0. The column was washed thoroughly with the same buffer to remove unadsorbed materials and then the adsorbed materials were eluted by a liner gradient of 0.15 to $0.55 \mathrm{M} \mathrm{NaCl}$ in the same buffer $(180 \mathrm{~mL})$, and the elution was continued using $2 \mathrm{M} \mathrm{NaCl}$ in the same buffer $(40 \mathrm{~mL})$ at a flow rate of $1 \mathrm{~mL} / \mathrm{min}$.

\section{Measurement of Protease Activity}

The proteolytic activity was determined as described previously with some modifications (Kumura et al., 1991). The substrate, $0.5 \%$ casein dissolved in $0.05 \mathrm{M}$ sodium phosphate buffer at $\mathrm{pH} 6.0(700 \mu \mathrm{L})$, was incubated with an appropriately diluted enzyme solution $(50 \mu \mathrm{L})$ at a defined temperature for $1 \mathrm{~h}$. The reaction was terminated by the addition of $15 \%$ trichloroacetic acid solution $(750 \mu \mathrm{L})$, and further incubation was carried out for $15 \mathrm{~min}$. The resulting preparation was centrifuged at $10,000 \times g$ and $25^{\circ} \mathrm{C}$ for 15 min to obtain the supernatant. The optical density at $280 \mathrm{~nm}$ was measured to calculate the protease activity. One unit of protease (PU) was expressed as the amount of the protease that allows an increase in the optical density of the substrate at $280 \mathrm{~nm}$ of 0.001 per 1 min. Unless otherwise mentioned, incubation was carried out at $30^{\circ} \mathrm{C}$. Alternatively, casein was dissolved in $0.05 \mathrm{M}$ sodium citrate or $0.05 \mathrm{M}$ sodium borate to adjust to the desired $\mathrm{pH}$ value.

\section{Analysis of Whey Protein Hydrolysis}

The degradation profile of whey protein by fungal protease was investigated by HPLC. One milliliter of $0.5 \%$ WPI dissolved in $0.05 \mathrm{M}$ sodium phosphate at $\mathrm{pH} 6.0$ was mixed with $2 \mathrm{U}$ of crude enzyme or individual component, filter-sterilized and incubated at $30^{\circ} \mathrm{C}$ for 24 or 72 h. The resulting solution was injected into the HPLC.

Furthermore, heat-aggregated whey protein was used as a substrate; cheese whey obtained from an experimental factory at Hokkaido University was adjusted to $\mathrm{pH} 6.0$ using lactic acid and heated above $95^{\circ} \mathrm{C}$ for 10 min in boiling water. After cooling to room temperature, the precipitate was collected by centrifugation at $10,000 \times g$ and $25^{\circ} \mathrm{C}$ for $10 \mathrm{~min}$. The precipitates of 20-mg wet weight were transferred to a test tube and dispersed in $1 \mathrm{~mL}$ of $0.05 \mathrm{M}$ sodium phosphate buffer at $\mathrm{pH} 6.0$, containing $0.05 \% \mathrm{NaN}_{3}$ and $2 \mathrm{U}$ of proteolytic activity in the form of the crude enzyme equivalent. The test tube was incubated at $30^{\circ} \mathrm{C}$ for $24 \mathrm{~h}$ and centrifuged at $10,000 \times g$ and $4^{\circ} \mathrm{C}$ for 10 min to recover the supernatant as the sample for HPLC.

The samples described above were loaded on a TSK gel ODS-100S column $(4.6 \times 150 \mathrm{~mm}$; Tosoh, Tokyo, Japan). As the starting solvent, $0.1 \%$ trifluoroacetic acid in water was used. Elution was performed by a 

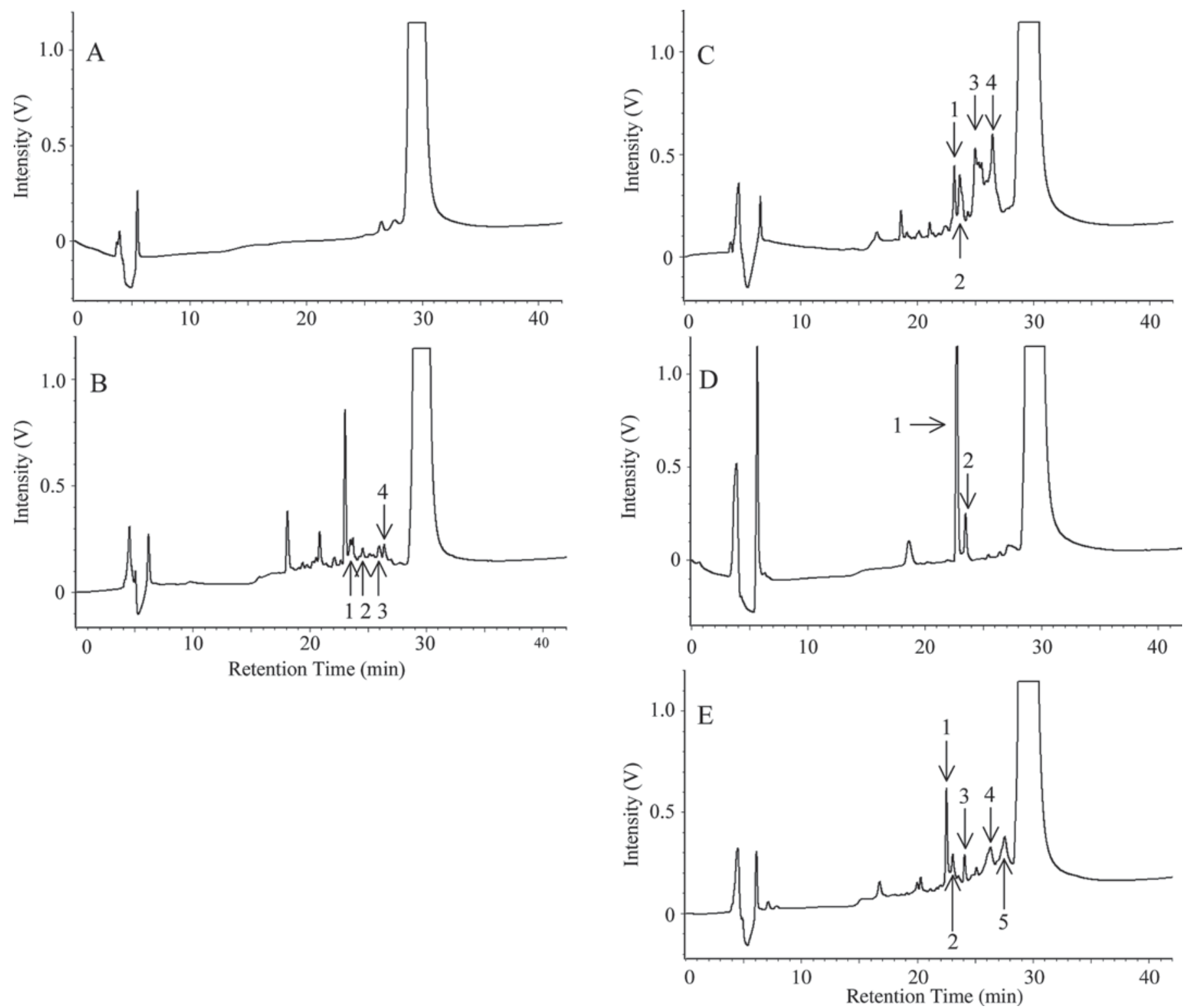

Figure 1. Liquid chromatography of the whey protein isolate (WPI) hydrolysate. The digestion was carried out using an amount equivalent to $2 \mathrm{U}$ of protease at $30^{\circ} \mathrm{C}$. (A) Unhydrolyzed WPI; (B) digested by crude enzyme from Aspergillus oryzae AHU7146 for $72 \mathrm{~h}$; (C) digested by component 1 for $24 \mathrm{~h}$; (D) digested by component 2 for $72 \mathrm{~h}$; (E) digested by component 3 for $24 \mathrm{~h}$. The constituents of the numbered fractions were subjected to N-terminal amino acid sequence analysis, and the results are shown in Table 2.

linear gradient of acetonitrile, 0 to $100 \%$ in 35 min, at a flow rate of $0.4 \mathrm{~mL} / \mathrm{min}$, and fractions were collected. The N-terminal amino acid sequence of fragments in selected fractions was determined by means of a protein sequencer (Procise 491 cLC, Applied Biosystems, Austin, TX). The cleavage sites were identified on the basis of the probable amino acid sequence of the released peptide fractions that corresponded to at least 4 serial amino acids that correspond to $\beta-\mathrm{LG}, \alpha-\mathrm{LA}$, and glycomacropeptide.

\section{Protein Determination and Zymography}

The protein concentration was determined using a modified Lowry method (Peterson, 1977) with BSA as a standard.

Zymography was carried out according to the method of Raser et al. (1995) with slight modification. In brief, a separating gel containing $0.2 \%$ of WPI was used. After electrophoresis, the gels were incubated in a $0.02 \mathrm{M}$ sodium phosphate buffer at $\mathrm{pH} 6.0$ with slow shaking 

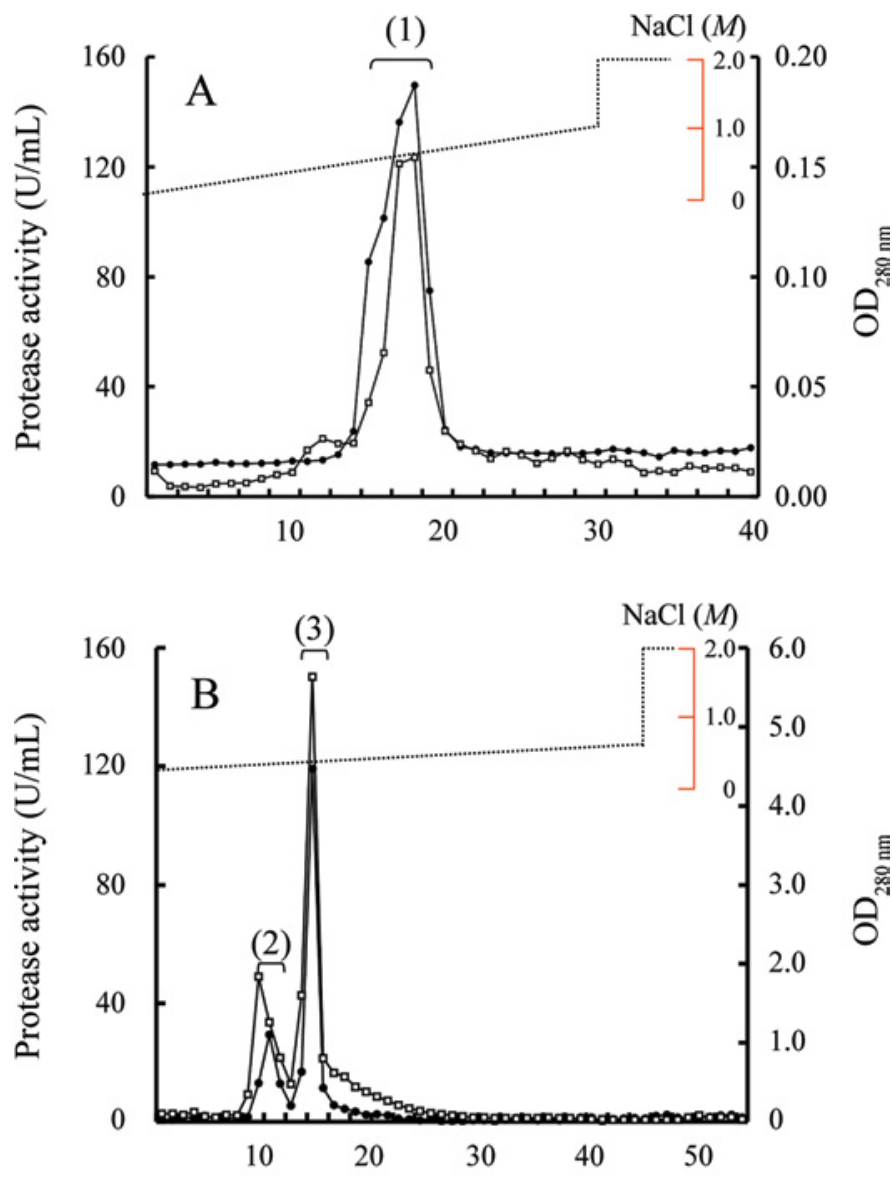

Fraction no.

Figure 2. Ion-exchange chromatography profile of the proteolytic active fractions obtained from the Butyl-Toyopearl 650S adsorptive (A) and nonadsorptive (B) component. The DEAE-Toyopearl $650 \mathrm{M}$ was used for separation with a $0.02 M$ sodium phosphate buffer at $\mathrm{pH}$ 6.0 as the starting solvent, followed by a gradient of $\mathrm{NaCl}$. The amount of protein was measured at an absorbance of $280 \mathrm{~nm}(\square)$, and the enzyme activity $(\bullet)$ is also shown. Indicated fractions were pooled and used as components 1,2 , and 3 in the subsequent experiments. OD = optical density. Color version available in the online PDF.

for $30 \mathrm{~min}$. The gels were further incubated overnight at ambient temperature in the same buffer. Finally, the gels were stained with Coomassie blue R-250 (Nacalai Tesque, Kyoto, Japan).

\section{RESULTS}

\section{Effect of Temperature and $\mathrm{pH}$ on Protease Synthesis}

Aspergillus oryzae AHU7146 was grown under various $\mathrm{pH}$ and temperature conditions to induce protease activity. As shown in Table 1, at the 2-wk time point, large amounts of protease activity were detected when the $\mathrm{pH}$ value and temperature were adjusted to 6.0 and $25^{\circ} \mathrm{C}$, respectively. Even if the incubation at $25^{\circ} \mathrm{C}$ was continued up to $4 \mathrm{wk}$, no accumulation of the activity
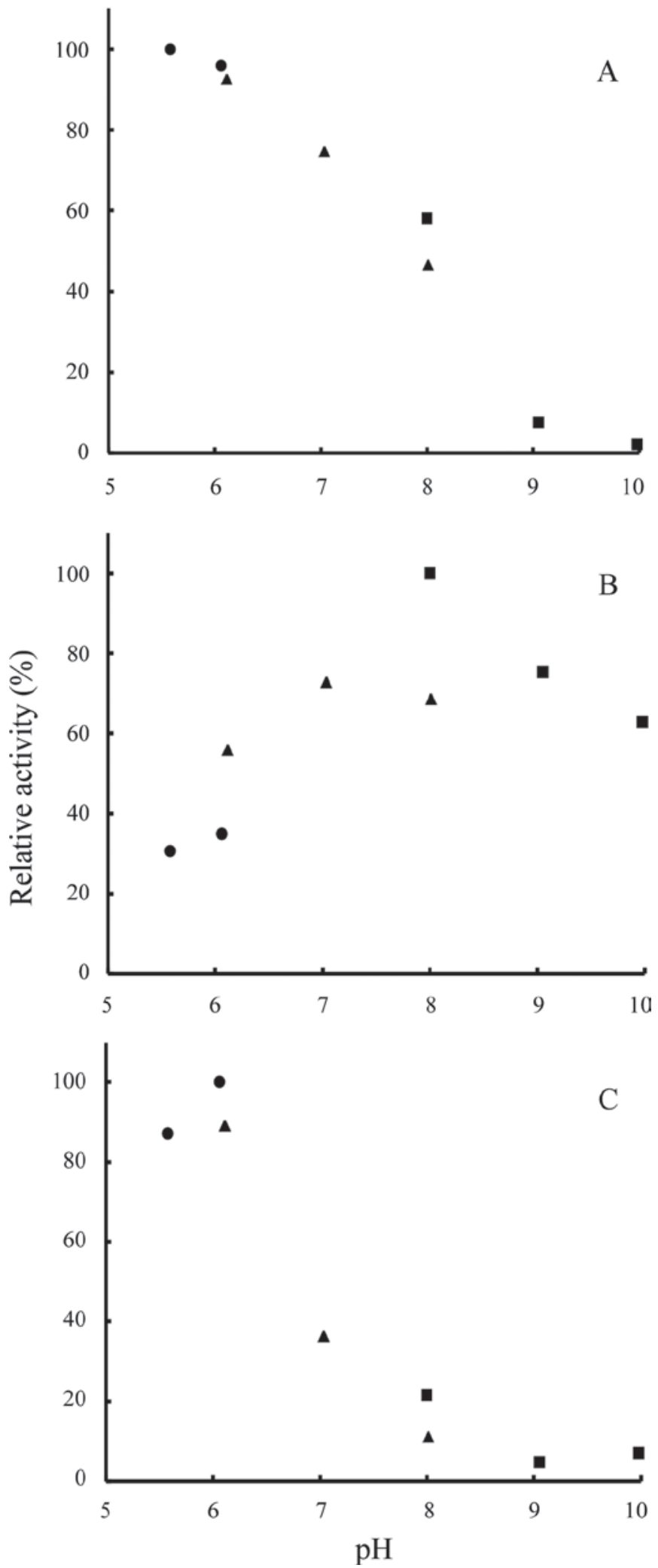

Figure 3. Effect of $\mathrm{pH}$ on the proteolytic activity of the components $1(\mathrm{~A}), 2(\mathrm{~B})$, and $3(\mathrm{C})$ at $30^{\circ} \mathrm{C}$ using $0.5 \%$ casein substrate dissolved in $0.05 \mathrm{M}$ sodium citrate $(\bullet), 0.05 \mathrm{M}$ sodium phosphate ( $\mathbf{\Delta})$, or $0.05 \mathrm{M}$ sodium borate (ם) buffer. 
Table 2. Probable sequence of the peptide obtained by HPLC

\begin{tabular}{|c|c|c|c|c|c|}
\hline $\begin{array}{l}\text { Probable origin } \\
\text { of the fragment }\end{array}$ & $\begin{array}{l}\text { Possible } \\
\text { sequence of AA }\end{array}$ & $\begin{array}{l}\text { AA } \\
\text { position }\end{array}$ & Substrate & Enzyme $^{1}$ & $\begin{array}{l}\text { HPLC } \\
\text { peak }\end{array}$ \\
\hline \multirow[t]{11}{*}{$\mathrm{GMP}^{2}$} & AIPPK & M106-A107 & $\mathrm{WPI}^{3}$ & 1 & Figure 1C-4 \\
\hline & & & Aggregates & $\mathrm{CE}$ & Figure $6 \mathrm{~B}-1-3$ \\
\hline & QDKTE & N113-Q114 & WPI & 3 & Figure 1E-1 \\
\hline & EIPT & T117-E118 & Aggregates & $\mathrm{CE}$ & Figure $6 \mathrm{~B}-1,2$ \\
\hline & TINT & P120-T121 & WPI & 1 & Figure 1C-4 \\
\hline & GEPTS & S127-G128 & WPI & 1 & Figure $1 \mathrm{C}-1-3$ \\
\hline & & & & 3 & Figure 1E-3, 4 \\
\hline & EVIE & P150-E151 & WPI & $\mathrm{CE}$ & Figure 1B-2-4 \\
\hline & SPPEI & E154-S155 & WPI & 2 & Figure 1D-1, 2 \\
\hline & & & & 3 & Figure 1E-1, 2, 4 \\
\hline & VQVT & T161-V162 & Aggregates & $\mathrm{CE}$ & Figure 6B-1 \\
\hline \multirow[t]{17}{*}{$\alpha-L A$} & LKDLK & E11-L12 & Aggregates & $\mathrm{CE}$ & Figure 6B-3 \\
\hline & SLPE & V21-S22 & WPI & 2 & Figure 1D-1 \\
\hline & AIVQ & Q39-A40 & Aggregates & $\mathrm{CE}$ & Figure 6B-1 \\
\hline & NDSTE & N44-N45 & Aggregates & $\mathrm{CE}$ & Figure 6B-3 \\
\hline & FQIN & L52-F53 & Aggregates & $\mathrm{CE}$ & Figure 6B-3 \\
\hline & FQINN & & WPI & $\mathrm{CE}$ & Figure 1B-2, 3 \\
\hline & NKIW & N56-N57 & WPI & $\mathrm{CE}$ & Figure 1B-3, 4 \\
\hline & KDDQN & C61-K62 & WPI & 1 & Figure $1 \mathrm{C}-1,2$ \\
\hline & & & WPI & 3 & Figure $1 \mathrm{E}-4$ \\
\hline & DQNP & D63-D64 & WPI & 1 & Figure 1C-4 \\
\hline & CDKF & $\mathrm{S} 76-\mathrm{C} 77$ & WPI & 3 & Figure 1E-1, 2 \\
\hline & DDLTD & D82-D83 & WPI & 3 & Figure $1 \mathrm{E}-4,5$ \\
\hline & TDDI & L85-T86 & WPI & 3 & Figure 1E-5 \\
\hline & KKIL & V92-K93 & Aggregates & $\mathrm{CE}$ & Figure $6 \mathrm{~B}-3$ \\
\hline & VGIN & K98-V99 & Aggregates & $\mathrm{CE}$ & Figure $6 \mathrm{~B}-3$ \\
\hline & GINY & V99-G100 & WPI & 1 & Figure 1C-4 \\
\hline & KLDQ & E113-K114 & Aggregates & $\mathrm{CE}$ & Figure 6B-4 \\
\hline \multirow[t]{20}{*}{$\beta-\mathrm{LG}$} & TMKGL & Q3-4T & WPI & 1 & Figure 1C-3, 4 \\
\hline & LDIQK & G9-L10 & WPI & 1 & Figure $1 \mathrm{C}-1,2$ \\
\hline & & & WPI & 3 & Figure 1E-3 \\
\hline & LKPT & E45-L46 & WPI & $\mathrm{CE}$ & Figure 1B-1 \\
\hline & EGDLE & P50-E51 & Aggregates & $\mathrm{CE}$ & Figure $6 \mathrm{~B}-3$ \\
\hline & GDLE & E51-G52 & WPI & 3 & Figure 1E-4 \\
\hline & LQKW & L57-L58 & WPI & 1 & Figure $1 \mathrm{C}-1,3,4$ \\
\hline & WENG & K60-W61 & WPI & 1 & Figure $1 \mathrm{C}-1,2$ \\
\hline & AEKTK & I72-A73 & WPI & 1 & Figure 1C-3 \\
\hline & & & WPI & 3 & Figure 1E-3, 4 \\
\hline & TKIPA & $\mathrm{K} 75-\mathrm{T} 76$ & Aggregates & $\mathrm{CE}$ & Figure 6B-3 \\
\hline & VLDT & L93-V94 & Aggregates & $\mathrm{CE}$ & Figure 6B-3, 4 \\
\hline & AEPEQ & S110-A111 & WPI & 3 & Figure $1 \mathrm{E}-4$ \\
\hline & EQSLA & P113-E114 & Aggregates & $\mathrm{CE}$ & Figure 6B-3 \\
\hline & VRTPE & L122-V123 & WPI & 1 & Figure 1C-3, 4 \\
\hline & KALP & L140-K141 & WPI & 1 & Figure $1 \mathrm{C}-2$ \\
\hline & LPMHI & A142-L143 & WPI & $\mathrm{CE}$ & Figure 1B-2 \\
\hline & SFNP & L149-S150 & WPI & 1 & Figure $1 \mathrm{C}-1,4$ \\
\hline & FNPT & S150-F151 & WPI & 3 & Figure 1E-1-5 \\
\hline & TQLEE & P153-T154 & WPI & 3 & Figure 1E-4 \\
\hline
\end{tabular}

${ }_{1}^{1}$ : Component 1; 2: component 2; 3: component 3; CE: crude enzyme. Component 1 was the adsorptive component of Butyl-Toyopearl 650S (details are shown in Figure 2A). Components 2 and 3 were nonadsorptive components of Butyl-Toyopearl 650S (details are shown in Figure 2B).

${ }^{2}$ Glycomacropeptide.

${ }^{3}$ Whey protein isolate.

was monitored. In contrast, incubation at $20^{\circ} \mathrm{C}$ for 4 wk resulted in activity comparable to that obtained at $25^{\circ} \mathrm{C}$ for 2 wk.

\section{Confirmation of Whey Protein Degradation Using Crude Enzyme by HPLC}

The WPI solution was treated with the crude enzyme prepared from A. oryzae AHU7146 grown on the solid-phase medium at $25^{\circ} \mathrm{C}$ for $2 \mathrm{wk}$. Due to the hydrolysis, several peaks appeared upon HPLC elution (Figure 1B), some of which were collected to analyze N-terminal amino acids. Some cleavage sites were successfully proposed and are listed in Table 2 .

\section{Fractionation of Protease in Crude Enzyme}

Because multiple proteolytic components were predicted to be involved in the activity of the crude enzyme, fractionation using column chromatography 
Table 3. Purification of protease from Aspergillus oryzae AHU7146

\begin{tabular}{lcccrc}
\hline Sample $^{1}$ & $\begin{array}{c}\text { Total volume } \\
(\mathrm{mL})\end{array}$ & $\begin{array}{c}\text { Total activity } \\
(\mathrm{U})\end{array}$ & $\begin{array}{c}\text { Specific activity } \\
(\mathrm{U} / \mathrm{mg})\end{array}$ & $\begin{array}{c}\text { Purification } \\
(\text { fold })\end{array}$ & $\begin{array}{c}\text { Yield } \\
(\%)\end{array}$ \\
\hline After extraction & 360 & 4,770 & 76 & 1.0 & 100 \\
Dialyzed crude enzyme & 23 & 3,900 & 229 & 3.0 & 81.8 \\
Ethanol-eluted fraction & 11 & 1,470 & 2,568 & 33.7 & 30.8 \\
Component 1 & 5 & 550 & 3,602 & 47.2 & 11.5 \\
Component 2 & 8 & 220 & 98 & 1.3 & 4.6 \\
Component 3 & 12 & 590 & 118 & 1.6 & 12.4 \\
\hline
\end{tabular}

${ }^{1}$ Component 1 was the adsorptive component of Butyl-Toyopearl 650S (details are shown in Figure 2A). Components 2 and 3 were nonadsorptive components of Butyl-Toyopearl 650S (details are shown in Figure $2 \mathrm{~B})$.

was performed. Even under a low salt concentration, some of the proteolytic components were adsorbed to the Butyl-Toyopearl ligand, and these components were successfully eluted by a gradient of buffered ethanol solution (data not shown). Figure 2 shows the elution profile of the fractions that were adsorptive or nonadsorptive to the hydrophobic ligand, which were then applied to a DEAE-Toyopearl column. The hydrophobic ligand absorptive fraction showed a homogeneous chromatographic profile and was recovered as component 1. The hydrophobic ligand nonabsorptive fraction resolved into 2 peaks on the DEAE column, and these peaks were recovered as components 2 and 3 . A representative result of purification is summarized in Table 3 .

\section{Partial Characterization of Individual Components}

Components 1 and 3 were acidic proteases, whereas component 2 retained its activity in the alkaline $\mathrm{pH}$ region (Figure 3). The maximum proteolytic activity was obtained at $50^{\circ} \mathrm{C}$ for components 1 and 3 , and at $40^{\circ} \mathrm{C}$ for component 2 (Figure 4 ).

The incubation of the WPI solution in the presence of each component led to the release of peptides, and several peaks appeared with HPLC elution (Figure 1 $\mathrm{C}-\mathrm{E})$. Some of them were collected to analyze N-terminal amino acids, and proposed cleavage sites are shown in Table 2. Although attempts to identify the substrate specificity toward $\beta$-LG of component 2 by HPLC were unsuccessful, the susceptibility of whey protein to this component was more evident than the others from the zymography (Figure 5). The electrophoretic mobility of component 1 was similar to that of component 3, whereas component 2 migrated more slowly.

\section{Digestion of Whey Protein Aggregates by Crude Enzyme}

To observe the accessibility of the crude enzyme to the aggregate form of whey protein, whey protein aggregates dispersed in a buffer solution were treated with the crude enzyme. Due to hydrolysis, several peaks appeared by HPLC elution (Figure 6), some of which were collected to analyze $\mathrm{N}$-terminal amino acids. Some cleavage sites were successfully proposed and listed in Table 2. At the end of the incubation, the sample was recovered to monitor bacterial contamination using standard plate count agar. Because the colony formation was undetectable, the effect of the bacterial protease was neglected (data not shown).

\section{DISCUSSION}

Our initial attempt was to induce proteases responsible for the degradation of whey protein with fungi used in cheese production, such as $P$. roqueforti and $P$. camemberti, in a modified Czapek-Dox medium whose nitrogen source was replaced by WPI, as was in this study. Although the growth of these fungi was possible, the secretion of protease was so poor that we selected $A$. oryzae as an alternative enzyme source.

In this study, the secreted protease activity was the highest if the $\mathrm{pH}$ value and temperature were adjusted to 6.0 and $25^{\circ} \mathrm{C}$, respectively. Under the condition of the liquid-phase medium comprising the same constituents at $25^{\circ} \mathrm{C}$ for $2 \mathrm{wk}$, the secreted proteolytic activity from A. oryzae AHU7146 was negligible (data not shown). It is well known that solid-phase media are preferable to submerged culture for enzyme production by $A$. oryzae (Kitano et al., 2002; Te Biesebeke et al., 2005). Although this study was intended to induce proteases able to hydrolyze whey protein, casein was found to be preferable as the substrate to enhance the sensitivity of the assay. Therefore, in addition to the observation concerning the effect of temperature and $\mathrm{pH}$ on the protease synthesis of $A$. oryzae AHU7146, the purification and characterization of individual components were carried out using casein as the substrate.

By means of column chromatography, the crude enzyme was fractionated into 3 proteolytic components. Components 1 and 3 exhibited similar properties with respect to optimal temperature, electrophoretic mobility during zymographic analysis, and the ability to digest $\beta$-LG and $\alpha$-LA in WPI solution, although component 


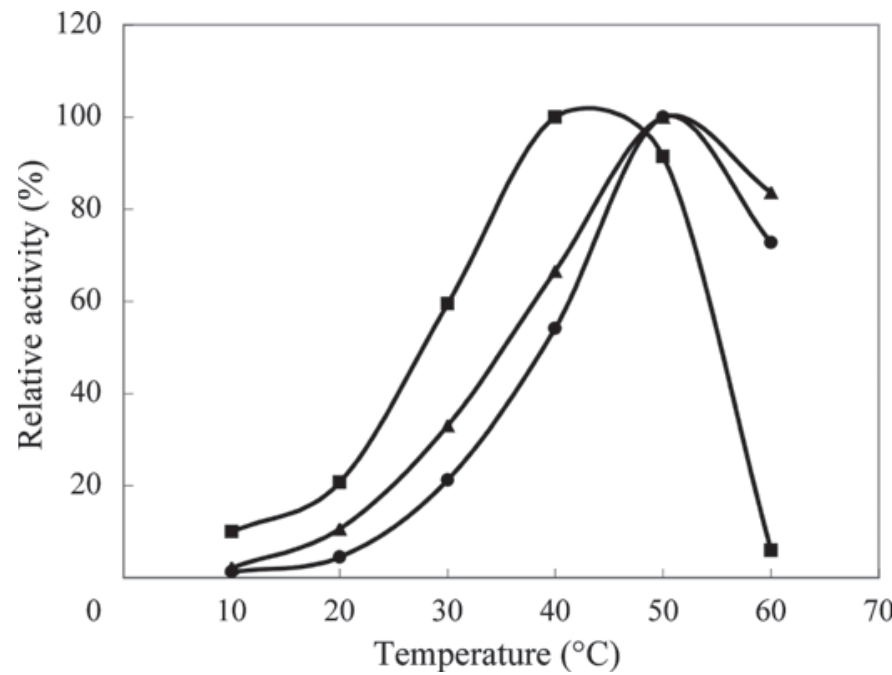

Figure 4. Effect of temperature on the proteolytic activity of components $1(\bullet), 2(\mathbf{\square})$, and $3(\boldsymbol{\Delta})$ at $\mathrm{pH} 6.0$.

1 was more hydrophobic and still active in the neutral $\mathrm{pH}$ region. Component 2 was less abundant than the other components and retained activity in the alkaline $\mathrm{pH}$ region.

Because of the small quantities obtained, information such as molecular weight, the amino acid sequence and isoelectric point of the individual components remain unclear. Vishwanatha et al. (2010) adapted a responsesurface methodology to induce the acid protease from A. oryzae MTCC 5341 and concluded that its optimum factor levels were $\mathrm{pH} 5.4$, incubation at a temperature of $31^{\circ} \mathrm{C}$, and $123 \mathrm{~h}$ as the fermentation time. It might be possible to modify the resulting ratio of the 3 components obtained in our study if these factors are

A

B

$\mathrm{C}$

$\mathrm{D}$

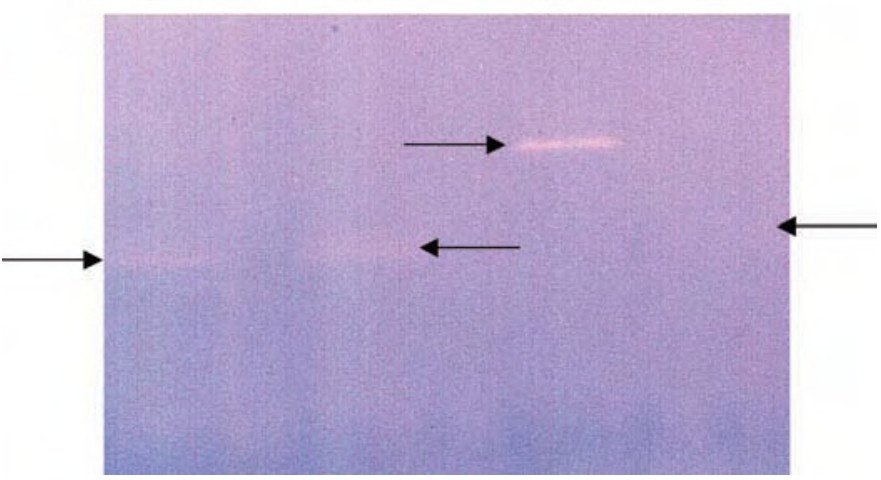

Figure 5. Zymograms using whey protein isolate as the substrate An amount equivalent to $2 \mathrm{U}$ of protease as a crude enzyme (lane A), component 1 (lane B), component 2 (lane C), and component 3 (lane D) were subjected to the gel. Arrows indicate the transparent band. Color version available in the online PDF.
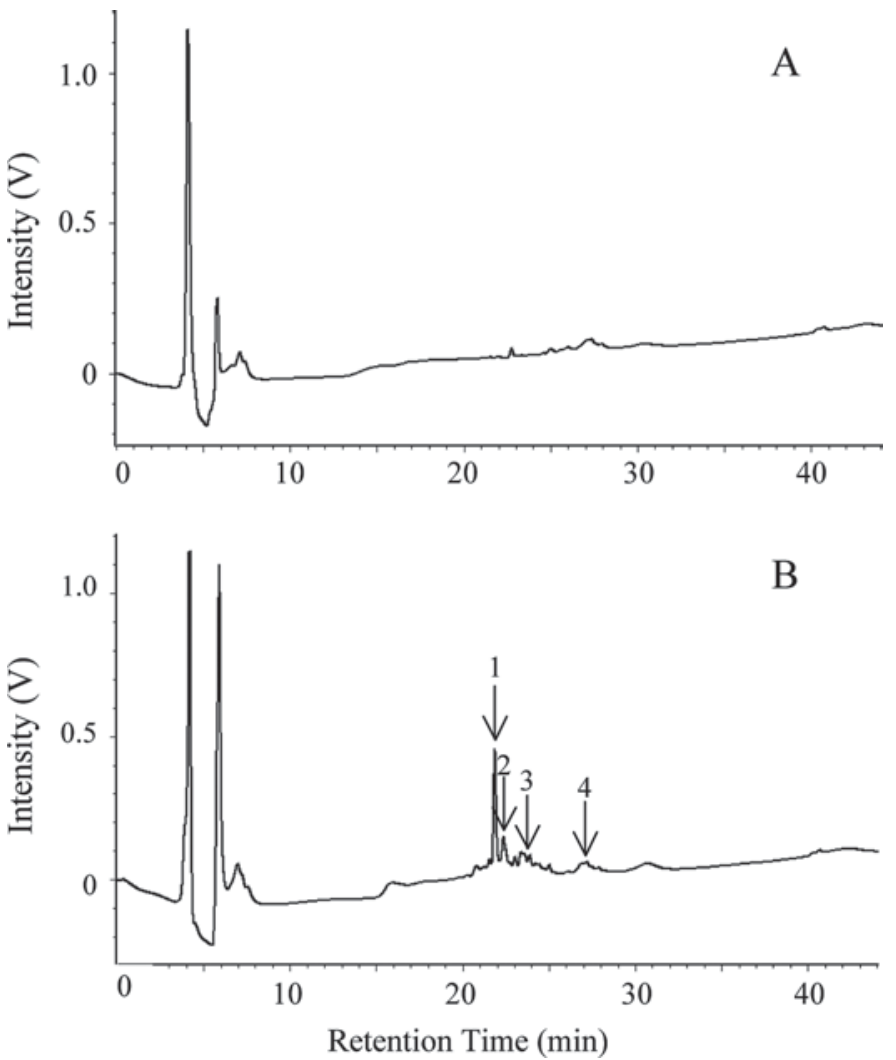

Figure 6. Liquid chromatography of the hydrolysate from whey protein aggregates dispersed in a buffer system: (A) indicates that no enzyme was added; (B) indicates digestion by the crude enzyme equivalent to $2 \mathrm{U}$ of protease from Aspergillus oryzae AHU7146 at $30^{\circ} \mathrm{C}$ for $24 \mathrm{~h}$. The chromatography was performed using a TSK gel ODS-100S column $(4.6 \times 150 \mathrm{~mm}$; Tosoh, Tokyo, Japan $)$ with $0.1 \%$ trifluoroacetic acid as the starting solvent, followed by a gradient of acetonitrile. The constituents of the numbered fractions were subjected to N-terminal amino acid sequence analysis, and results are shown in Table 2.

carefully considered. Furthermore, a genomic database is advantageous to develop microarray analysis, which will help in the identification of molecular species for the corresponding proteinases.

The degradation of $\beta-\mathrm{LG}$ and $\alpha-\mathrm{LA}$ in the WPI solution induced by the crude enzyme was primarily due to the action of components 1 and 3; however, the proposed cleavage sites identified using a crude enzyme preparation were inconsistent with those of the individual components, which was attributed to the concomitant peptidases in the preparation of crude enzyme. Indeed, the identification of cleavage sites using the crude enzyme was more difficult, which was interpreted as the result of extensive degradation by the synergic action of proteinases and peptidases. Mizuno et al. (2004) compared the hydrolysis of casein using 9 different commercially available proteases and found that the preparation using protease from $A$. oryzae 
A

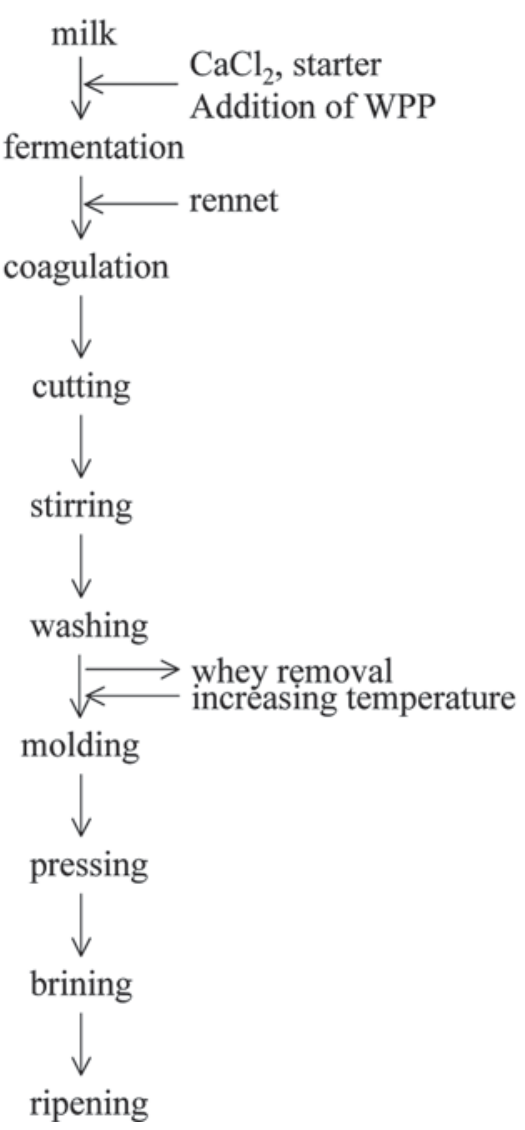

$\mathrm{B}$

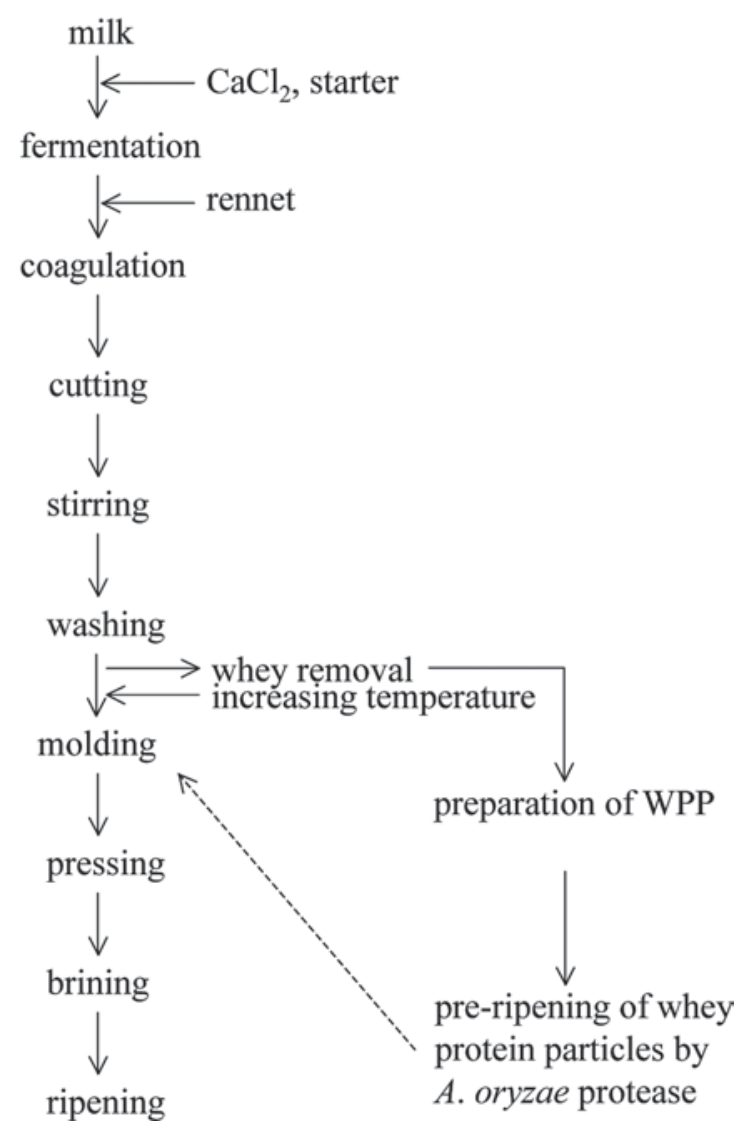

Figure 7. Process modification in the manufacturing of soft, semi-hard, and hard cheeses when whey protein particles (WPP) are added. Scheme (A) is from Hinrichs (2001); (B) is an alternative strategy to incorporate WPP into cheese curd. A. oryzae = Aspergillus oryzae.

showed the shortest average peptide length of $1.4 \mathrm{AA}$ in the sequence and the highest angiotensin-I converting enzyme inhibitory activity. In contrast, Izumi et al. (2009) demonstrated that the oral administration of hydrolysates of $\alpha$-LA by commercial protease from $A$. oryzae significantly promoted small intestinal elongation and increased the number of crypt epithelial cells compared with intact $\alpha$-LA. They treated $\alpha$-LA with the commercial protease at a $\mathrm{pH}$ of 7.0 , and at the end of the incubation at $50^{\circ} \mathrm{C}$ for $18 \mathrm{~h}$, the average molecular weight of the resulting peptides was 545, which was longer than that obtained from casein digestion. In this study, we identified the cleavage sites on the basis of the probable AA sequence of the released peptide consistent with at least 4 serial AA residues; however, it was possible to involve peptides composed of fewer than 3 amino acids.

Britten et al. (1994) incubated WPI with a commercial protease from $A$. oryzae under alkaline conditions $(\mathrm{pH} 8)$ and observed the preferential hydrolysis of $\beta$-LG and resistance of $\alpha-\mathrm{LA}$ and BSA to the protease. The results suggest that the protease involved in the prepa- ration was different from the 3 components used in the current study with respect to optimal $\mathrm{pH}$ region and substrate specificity. Rao et al. (1998) reviewed microbial proteases and described that the fungal acid protease had its optimum $\mathrm{pH}$ between 4 and 4.5. Components 1 and 3 were acid proteases; however, the proteolytic activity could not be determined using casein as the substrate at this $\mathrm{pH}$ because of the poor solubility of the casein. The application of other substrates such as hemoglobin and cytochrome c will clarify the effect of acidic $\mathrm{pH}$ on the activity and facilitate its comparison with other acidic proteases from A. oryzae. Vishwanatha et al. (2009) found that the acid protease from A. oryzae MTCC 5341 preferred hydrophobic amino acids as the cleavage site; however, 3 components in this study showed broad specificity.

Although no cleavage site of component 2 was found in $\beta$-LG, zymography demonstrated that proteolysis induced by component 2 was evident. It should be considered that zymography was carried out in the presence of surfactant, which could influence both the substrate structure and the catalytic properties. Tujita and Endo 
(1978) reported a membrane acid protease in A. oryzae that was activated in the presence of Triton X-100. Moreover, $\beta$-LG exhibits oligomeric form between $\mathrm{pH}$ 3.5 and 6.5 (Sawyer, 2003). These factors would affect the conformation of the substrate and lead to the alteration of enzyme accessibility. Therefore, the substrate specificity of these components should be carefully interpreted, with the properties of the substrate and hydrolytic environment taken into account. The HPLC elution profile of heat-denatured whey protein digested by the crude enzyme for $24 \mathrm{~h}$ (Figure 6B) was similar to that for $72 \mathrm{~h}$ (data not shown). In contrast, accumulation of hydrolysate from WPI digested by the crude enzyme was monitored when the HPLC profile after incubation for $72 \mathrm{~h}$ (Figure 1B) was compared with that after $24 \mathrm{~h}$ (data not shown). The result was, in part, due to the limitation of accessibility of the enzyme to the aggregated form of the denatured protein, and fine particulation of the heat-denatured whey protein would stimulate liberation of the peptide. Thus, even if the whey protein had been heat denatured, that is, aggregate form prepared by heating cheese whey, it can be concluded that the aggregate form would be digested by the crude enzyme from $A$. oryzae.

In conclusion, the 3 components associated with the degradation of whey protein were isolated when a solidphase medium containing WPI as the nitrogen source was used for growth of $A$. oryzae AHU7146. Figure 7A shows the schema of cheese manufacture attempted by the addition of whey protein particles (Hinrichs, 2001), and it is of interest to postulate an alternative process as indicated in Figure 7B: the application of the proteolytic system of $A$. oryzae to heat-denatured whey protein particles for pre-ripening. Following maturation under optimal conditions, the material will be mixed with curd before pressing so that the curd will receive the pre-ripened whey protein as not only a nutritional additive but also as an adjunct to stimulate the ripening of the cheese matrix. For this purpose, further studies are needed, including the formulation of a protease mixture from $A$. oryzae and the adjustment of the amount of the enzyme and ripening circumstances such as temperature, $\mathrm{pH}$, and incubation period to develop an acceptable flavor.

\section{ACKNOWLEDGMENTS}

The authors are very grateful to Teruo Sone, Research Faculty of Agriculture, Hokkaido University for helpful discussion. We also thank Shouji Hioki, Yukiko Kuzuma, and Minoru Ikuta, Field Science Center for Northern Biosphere, Hokkaido University for the supply of cheese whey.

\section{REFERENCES}

Barbesgaard, P., H. P. Heldt-Hansen, and B. Diderichsen. 1992. On the safety of Aspergillus oryzae: A review. Appl. Microbiol. Biotechnol. 36:569-572.

Britten, M., H. J. Giroux, and V. Gaudin. 1994. Effect of pH during heat processing of partially hydrolyzed whey protein. J. Dairy Sci. 77:676-684.

Cozzolino, A., P. Di Pierro, L. Mariniello, A. Sorrentino, P. Masi, and R. Porta. 2003. Incorporation of whey proteins into cheese curd by using transglutaminase. Biotechnol. Appl. Biochem. 38:289-295.

Dickinson, E. 2003. Interfacial emulsifying and foaming properties of milk proteins. Pages 1229-1260 in Advanced Dairy Chemistry: Vol. 1: Proteins, Part B. 3rd ed. P. F. Fox and P. L. H. McSweeney, ed. Kluwer Academic/Plenum Publishers, New York, NY.

Fairbairn, D. J., and B. A. Law. 1986. Proteinases of psychrotrophic bacteria: Their production, properties, effects and control. J Dairy Res. 53:139-177.

FitzGerald, R. J., and H. Meisel. 2003. Milk protein hydrolysates and bioactive peptides. Pages 675-698 in Advanced Dairy Chemistry: Vol. 1: Proteins, Part B. 3rd ed. P. F. Fox and P. L. H. McSweeney, ed. Kluwer Academic/Plenum Publishers, New York, NY.

Hambræus, L., and B. Lönnerdal. 2003. Nutritional aspects of milk proteins. Pages 605-645 in Advanced Dairy Chemistry: Vol. 1: Proteins, Part B. 3rd ed. P. F. Fox and P. L. H. McSweeney, ed. Kluwer Academic/Plenum Publishers, New York, NY.

Hinrichs, J. 2001. Incorporation of whey proteins in cheese. Int. Dairy J. $11: 495-503$.

Hoppe, G. K., and J. J. Higgins. 1992. Demineralization. Pages 91-131 in Whey and Lactose Processing. J. G. Zadow, ed. Elsevier Applied Science, London and New York, NY.

Izumi, H., S. Ishizuka, A. Inafune, T. Hira, K. Ozawa, T. Shimizu, M. Takase, and H. Hara. 2009. Alpha-Lactalbumin hydrolysate stimulates glucagon-like peptide-2 secretion and small intestinal growth in suckling rats. J. Nutr. 139:1322-1327.

Kitano, H., K. Kataoka, K. Furukawa, and S. Hara. 2002. Specific expression and temperature-dependent expression of the acid protease-encoding gene (pepA) in Aspergillus oryzae in solid-state culture (Rice-Koji). J. Biosci. Bioeng. 93:563-567.

Kumura, H., K. Mikawa, and Z. Saito. 1991. Influence of concomitant protease on the thermostability of lipase of psychrotrophic bacteria. Milchwissenschaft 46:144-149.

Machida, M. 2002. Progress of Aspergillus oryzae genomics. Adv. Appl. Microbiol. 51:81-106.

Machida, M., K. Asai, M. Sano, T. Tanaka, T. Kumagai, G. Terai, K. Kusumoto, T. Arima, O. Akita, Y. Kashiwagi, K. Abe, K. Gomi, H. Horiuchi, K. Kitamoto, T. Kobayashi, M. Takeuchi, D. W. Denning, J. E. Galagan, W. C. Nierman, J. Yu, D. B. Archer, J. W. Bennett, D. Bhatnagar, T. E. Cleveland, N. D. Fedorova, O. Gotoh, H. Horikawa, A. Hosoyama, M. Ichinomiya, R. Igarashi, K. Iwashita, P. R. Juvvadi, M. Kato, Y. Kato, T. Kin, A. Kokubun, H. Maeda, N. Maeyama, J. Maruyama, H. Nagasaki, T. Nakajima, K. Oda, K. Okada, I. Paulsen, K. Sakamoto, T. Sawano, M. Takahashi, K. Takase, Y. Terabayashi, J. R. Wortman, O. Yamada, Y. Yamagata, H. Anazawa, Y. Hata, Y. Koide, T. Komori, Y. Koyama, T. Minetoki, S. Suharnan, A. Tanaka, K. Isono, S. Kuhara, N. Ogasawara, and H. Kikuchi. 2005. Genome sequencing and analysis of Aspergillus oryzae. Nature 438:1157-1161.

Madureira, A. R., T. Tavares, A. M. Gomes, M. E. Pintado, and F. X. Malcata. 2010. Invited review: Physiological properties of bioactive peptides obtained from whey proteins. J. Dairy Sci. 93:437-455.

Mangino, M. E. 1992. Properties of whey protein concentrates. Pages 231-270 in Whey and Lactose Processing. J. G. Zadow, ed. Elsevier Applied Science, London and New York, NY.

Mizuno, S., S. Nishimura, K. Matsuura, T. Gotou, and N. Yamamoto. 2004. Release of short and proline-rich antihypertensive peptides from casein hydrolysate with an Aspergillus oryzae protease. J. Dairy Sci. 87:3183-3188.

Morisawa, Y., A. Kitamura, T. Ujihara, N. Zushi, K. Kuzume, Y Shimanouchi, S. Tamura, H. Wakiguchi, H. Saito, and K. Matsumoto. 2009. Effect of heat treatment and enzymatic digestion 
on the B cell epitopes of cow's milk proteins. Clin. Exp. Allergy 39:918-925.

Mulvihill, D. M., and M. P. Ennis. 2003. Functional milk proteins: Production and utilization. Pages 1175-1228 in Advanced Dairy Chemistry: Vol. 1: Proteins, Part B. 3rd ed. P. F. Fox and P. L. H. McSweeney, ed. Kluwer Academic/Plenum Publishers, New York, NY.

Peñas, E., H. Snel, R. Floris, G. Préstamo, and R. Gomez. 2006. High pressure can reduce the antigenicity of bovine whey protein hydrolysates. Int. Dairy J. 16:969-975.

Peterson, G. L. 1977. A simplification of the protein assay method of Lowry et al. which is more generally applicable. Anal. Biochem. $83: 346-356$

Rao, M. B., A. M. Tanksale, M. S. Ghatge, and V. V. Deshpande. 1998. Molecular and biotechnological aspects of microbial proteases. Microbiol. Mol. Biol. Rev. 62:597-635.

Raser, K. J., A. Posner, and K. K. Wang. 1995. Casein zymography: A method to study mu-calpain, m-calpain, and their inhibitory agents. Arch. Biochem. Biophys. 319:211-216.

Sawyer, L. 2003. Beta-lactoglobulin. Pages 319-386 in Advanced Dairy Chemistry: Vol. 1: Proteins, Part A. 3rd ed. P. F. Fox and P. L. H. McSweeney, ed. Kluwer Academic/Plenum Publishers, New York, NY.

Singh, H., and P. Havea. 2003. Thermal denaturation, aggregation and gelation of whey proteins. Pages 1261-1287 in Advanced Dairy Chemistry: Vol. 1: Proteins, Part B. 3rd ed. P. F. Fox and P. L. H.
McSweeney, ed. Kluwer Academic/Plenum Publishers, New York, NY.

Taylor, M. J., and T. Richardson. 1979. Applications of microbial enzymes in food systems and in biotechnology. Adv. Appl. Microbiol. 25:7-35.

te Biesebeke, R., N. van Biezen, W. M. de Vos, C. A. van den Hondel, and P. J. Punt. 2005. Different control mechanisms regulate glucoamylase and protease gene transcription in Aspergillus oryzae in solid-state and submerged fermentation. Appl. Microbiol. Biotechnol. $67: 75-82$.

Tsujita, Y., and A. Endo. 1978. Purification and characterization of the two molecular forms of membrane acid protease from Aspergillus oryzae. Eur. J. Biochem. 84:347-353.

Vishwanatha, K. S., A. G. Appu Rao, and S. A. Singh. 2009. Characterization of acid protease expressed from Aspergillus oryzae MTCC 5341. Food Chem. 114:402-407.

Vishwanatha, K. S., A. G. Appu Rao, and S. A. Singh. 2010. Acid protease production by solid-state fermentation using Aspergillus oryzae MTCC 5341: Optimization of process parameters. J. Ind. Microbiol. Biotechnol. 37:129-138.

Yu, J., R. H. Proctor, D. W. Brown, K. Abe, K. Gomi, M. Machida, F. Hasegawa, W. C. Nierman, D. Bhatnagar, and T. E. Cleveland. 2004. Genomics of economically significant Aspergillus and Fusarium species. Pages 249-283 in Applied Mycology and Biotechnology, Vol. 4, Fungal Genomics. D. K. Arora and G. G. Khachatourians, ed. Elsevier, Amsterdam, the Netherlands. 